\title{
Infiltration of Prostate Cancer by CD204+ and CD3+ Cells Correlates with ERG Expression and TMPRSS2-ERG Gene Fusion
}

\author{
Infiltrace karcinomů prostaty CD204+ a CD3+ buňkami koreluje \\ s expresí ERG a fúzí genu TMPRSS2-ERG
}

\author{
Burdova A. ${ }^{1,2}$, Rulisek P. ${ }^{1}$, Bouchal J. ${ }^{1}$, Kral M. ${ }^{1}$, Student V. ${ }^{1}$, Kolar Z. ${ }^{1}$ \\ 'Department of Clinical and Molecular Pathology and Institute of Molecular and Translational \\ Medicine, Faculty of Medicine, Palacky University and University Hospital, Olomouc \\ ${ }^{2}$ Department of Medical Genetics, AGEL Laboratories, Nový Jičín
}

\begin{abstract}
Summary
Background: The aim of the study was to detect CD204 + and CD3 + cells in the infiltrate of benign prostatic hyperplasia, prostatic intraepithelial neoplasia and prostatic cancer in prostate specimens after radical prostatectomy. Another goal was to determine correlation of the intensity of the infiltration with ERG oncoprotein expression as well as with the presence of activating translocation TMPRSS2-ERG. Materials and Methods: To confirm the translocation, we used fluorescence in situ hybridization. Imunohistochemistry was used to detect the presence of ERG oncoprotein and for assesment of the number of CD204+ and CD3+ infiltrating cells. We determined the capability to infiltrate malignant structures according to differences in infiltration of benign and malignant prostate structures. Results: Biometric analysis confirmed that the number of CD204+ macrophages in the malignant structure was significantly higher than in the benign prostatic hyperplasia regardless of the fusion pattern. Increased infiltration by CD3+ cells was only detected in malignant structures of the prostate in a group with normal signal pattern and in a group with TMPRSS2-ERG fusion. Expression of ERG positively correlated with CD204+ and CD3+ cells infiltration of malignant structures only in cases where the TMPRSS2-ERG fusion was found. In the group with a break in the TMPRSS2 gene, a positive correlation was only found between ERG expression and CD204+ macrophages infiltration. In cases with a normal signal pattern, no correlation was found. In the group with TMPRSS2-ERG fusion we observed significantly more cases with a good capability of CD204+ cells to infiltrate malignant structures, unlike the group with a normal signal pattern, where there were more cases with the weak reactivity of CD204 + cells to infiltrate the malignant structures. The same was observed for CD3+ cells. CD204+ macrophages and CD3+ T-lymphocytes in the group with TMPRSS2-ERG gene fusion, infiltrated the malignant prostate structures more intensely, but their effect on malignant transformation may be different. Conclusions: The association between the presence of the TMPRSS2-ERG fusion and the different capability of inflammatory cells to infiltrate malignant structures has not been reported so far. The results confirm the important role of the activated ERG gene, due to TMPRSS2-ERG fusion, in the development of inflammation of the prostate as well as the effect of inflammatory cells on the course of neoplastic process. This leads to considerations about introducing immunomodulatory modalities into prostate cancer therapeutic protocols.
\end{abstract}

Key words

prostate cancer - TMPRSS2-ERG gene fusion - ERG - immune response - CD204+ macrophages - CD3+T-lymphocytes
This work was supported in part by grant LF 2018001 and grants NPS I LO1304 and DRO (UP, 61989592) from the Czech Ministry of Education.

Tato práce byla podpořena grantem LF_2018_001 a grantem NPS I LO1304 a DRO (UP, 61989592) Ministerstva školství České republiky.

The authors would like to thank dr. Katerina Langova for statistical evaluation and Ing. Ivo Uberall for photographic documentation.

Autoři děkují MUDr. Kateřině Langové za statistické vyhodnocení a Ing. Ivu Uberallovi za fotografickou dokumentaci.

The authors declare they have no potential conflicts of interest concerning drugs, products, or services used in the study.

Autoři deklarují, že $v$ souvislosti s předmětem studie nemaji žádné komerční zájmy.

The Editorial Board declares that the manuscript met the ICMJE recommendation for biomedical papers.

Redakční rada potvrzuje, že rukopis práce splnil ICMJE kritéria pro publikace zasilané do biomedicínských časopisů.

prof. MUDr. Zdeněk Kolář, CSc. Department of Clinical and Molecular Pathology Faculty of Medicine Palacky University in Olomouc Hnevotinska 3

77515 Olomouc

e-mail: zdenek.kolar@upol.cz

Submitted/Obdrženo: 5. 8. 2018 Accepted/Príijato: 25. 10. 2018

doi: $10.14735 / a m k o 2018421$ 


\begin{abstract}
Souhrn
Východiska: Cílem studie byla detekce CD204+ a CD3+ buněk v infiltrátu struktur benigní prostatické hyperplazie, prostatické intraepitelové neoplazie a prostatického karcinomu ve vzorcích prostaty po radikální prostatektomii a korelace intenzity této infiltrace s expresí onkoproteinu ERG i výskytem ERG aktivující translokace TMPRSS2-ERG. Materiál a metody: Detekce translokace byla provedena pomocí fluorescenční in situ hybridizace, detekce onkoproteinu ERG a fenotypu infiltrujících buněk byly provedeny imunohistochemicky. Př́pady byly dále rozděleny do podsouborů podle stupně infiltrace a rozdílů v infiltraci benigních a maligních struktur prostaty. Výsledky: Biometrická analýza potvrdila, že množství CD204+ makrofágů v infiltrátu maligních struktur se významně zvyšuje, a to bez ohledu na fúzní stav. Infiltrace CD3+ buňkami se v maligních strukturách zvyšovala pouze u prípadů s normálním stavem i u př́ipadů s prokázanou genovou fúzí. Exprese ERG pozitivně korelovala s infiltrací nádorového stromatu CD204+ makrofágy i CD3+ lymfocyty jen u prípadů s prokázaným fúzním genem. U př́padů s prokázanou přestavbou TMPRSS2 genu bez existence fúzního genu byla pozitivní korelace prokázána jen mezi expresí ERG a infiltrací CD204+ makrofágy. U negativních prípadů žádná korelace prokázána nebyla. Dále se ukázalo, že ve skupině s prokázaným fúzním genem je významně více prípadů s dobrou reaktivitou CD204+ buněk a ve skupině negativní naopak více případů se slabou reaktivitou CD204+ buněk. Stejný korelační vztah byl pozorován i v prípadě CD3+T lymfocytů. CD204+ makrofágy i CD3+T lymfocyty u případů s prokázaným fúzním genem tak infiltrovaly maligní struktury prostaty intenzivněji. Jejich funkce při malignizaci však je pravděpodobně rozdílná. Závěr: Tato asociace mezi přítomností fúzního genu TMPRSS2-ERG a rozdílnou schopností některých zánětlivých buněk infiltrovat maligní struktury v prostatě nebyla dosud popsána. Výsledky potvrzují důležitou úlohu aktivovaného genu $E R G$ při rozvoji zánětu v prostatě, stejně jako vliv zánětlivých buněk na rozvoj neoplastického procesu. Současně nabízejí možnost úvah o zařazení imunomodulačních postupů do terapeutického portfolia karcinomů prostaty.
\end{abstract}

Klíčová slova

karcinom prostaty - fúzní gen TMPRSS2-ERG - ERG - imunitní odpověd' - CD204+ makrofágy - CD3+T lymfocyty

\section{Introduction}

Chronic inflammation is an important cause of tumorigenesis in various types of malignancy, including prostate cancer (CaP) $[1,2]$. Inflammation may influence the pathogenesis of CaP by modifying the tumor microenvironment, remodelling the extracellular matrix and initiating epithelial-mesenchymal transition [3]. Inflammatory stress causes repeated genomic damage leading to transformation, vascularization, apoptosis and DNA mutations. Inflammatory cells secrete a number of cytokines that activate other stromal elements, promote tumor growth and initiate formation of metastasis. Inflammation correlates with an increased risk of developing proliferative inflammatory atrophy, and can mask prostatic intraepithelial neoplasia (PIN) or incipient carcinoma in benign prostatic hyperplasia (BPH), which may lead to misinterpretation of the examined biopsy $[4,5]$.

An important component of the tumor microenvironment are tumorassociated macrophages (TAMs) and tumor infiltrating dendritic cells that can induce immunosuppression and thus promote, in co-operation with infiltrating lymphocytes, tumor progression [6]. Macrophages are a major component of tumour infiltrating immune cells, which can promote cancer initiation, progression and metastasis.
TAMs infiltration has been shown to correlate with poor prognosis in cancers of breast, cervix, and bladder. However, it correlates probably with better prognosis for non-small cell lung cancer and colorectal cancer, which suggests distinct mechanisms in different tumor types and/or different tissue environments. Many studies have been carried out to look into macrophage associated markers in $\mathrm{CaP}$ samples using various cohort sizes and end points. However, the results remain controversial [7].

The ERG oncoprotein is known to be able to induce PIN, and in CaP cells, where it is expressed at $20-100 \times$ higher concentrations than in benign tissues, it stimulates prostaglandin mediated signalling. Androgen dependent induction of the ERG expression results from TMPRSS2-ERG gene fusion [8-10]. There is a possible link between the ability of the fusion gene to affect prostaglandin levels or generally, inflammation and the function of the pathway affected by cyclooxygenase-2, an enzyme that controls prostaglandin synthesis. Overexpression of ERG is also inversely proportional to the expression of 15-hydroxyl-prostaglandin dehydrogenase, an enzyme involved in prostaglandin degradation. The ability of prostaglandins to induce CaP growth, regulate expression of the urokinase- type plasminogen activator and contribute to tumor cell invasiveness has been demonstrated $[8,9]$.

In this study, we focused on determination a correlation between CD204+ macrophages and CD3+ T-lymphocytes infiltration in malignant, pre-malignant and benign prostate structures, expression of the ERG oncoprotein and the occurrence of the TMPRSS2-ERG gene fusion, respectively. A correlation could suggest the immunomodulatory role of ERG in CaP.

\section{Materials and methods}

Analysed cases were randomly selected from the tissue bank of the Department of Clinical and Molecular Pathology, Palacky University and University Hospital, Olomouc. They included archival formalin-fixed, paraffin-embedded tissue samples from 100 patients who had undergone radical prostatectomy between 2004-2011 for prostate adenocarcinoma in grades T1-T4, N0-N1, M0. Patients had not received hormonal or radiation therapy before the radical prostatectomy or adjuvant therapy before recurrence. The study was approved by the institutional ethics committee board. The morphological criteria for "normal", "BPH", "PIN" and "malignant prostatic epithelium" conformed to previously published definitions [11]. Sample sections were 
used for fluorescence in situ hybridization (FISH) analysis and for immunohistochemical detection of CD3, CD204 and ERG. ERG expression was evaluated using a commercial rabbit anti-ERG monoclonal antibody (clone EPR3864, Epitomics, Burlingame, California, USA), CD3 expression using a rabbit anti-CD3 polyclonal antibody (cat. no. AO452, Dako, Agilent Technologies, Santa Clara, California, USA) and CD204 expression using rabbit anti-CD-204 polyclonal antibody (cat. no. HPA000272-100VL, Sigma-Aldrich, St. Louis, Missouri, USA). The protocol for immunohistochemistry was as follows - slides were deparaffinized, exposed to heat-induced antigen retrieval in autoclave for $5 \mathrm{~min}$ at $121{ }^{\circ} \mathrm{C}$ and $\mathrm{pH} 7.8$ (ERG) and blocked with preantibody solution (10 $\mathrm{min}$ ). The antibody against ERG was applied in a dilution $1: 400$ for $60 \mathrm{~min}$ at room temperature. Primary antibodies were visualized using the DAKO EnVision Kit (Dako, Agilent Technologies, Santa Clara, California, USA) according to producer recommendations and 3.3'-diaminobenzidine $(20 \mathrm{~min}$, Sigma Fast 3.3'-diaminobenzidine tablets). Sections were then counterstained with hematoxylin, dehydrated, cleared, mounted, and covered. Only nuclear staining of ERG was scored using the $\mathrm{H}$-score system obtained by multiplying the intensity of the stain ( 0 - no staining; 1 - weak staining; 2 - moderate staining; 3 intense staining) by the percentage $(0-100)$ of cells showing that staining intensity (H-score range, 0-300). For negative controls, the primary antibodies were omitted. As positive control for CD3 and CD204 expression, the positivities of tissue lymphocytes and macrophages were used.

We had previously performed FISH for determination of the TMPRSS2-ERG gene fusion in this cohort of patients [12]. According to observed signal patterns, individual cases were divided into 3 groups, see below. The assessment was performed as follows - FISH analysis was carried out using Poseidon TMPRSS2-ERG (21q22) Del, Break, TC Probe (Kreatech Diagnostics, Amsterdam, The Netherlands), which is optimised to detect deletion between TMPRSS2 and

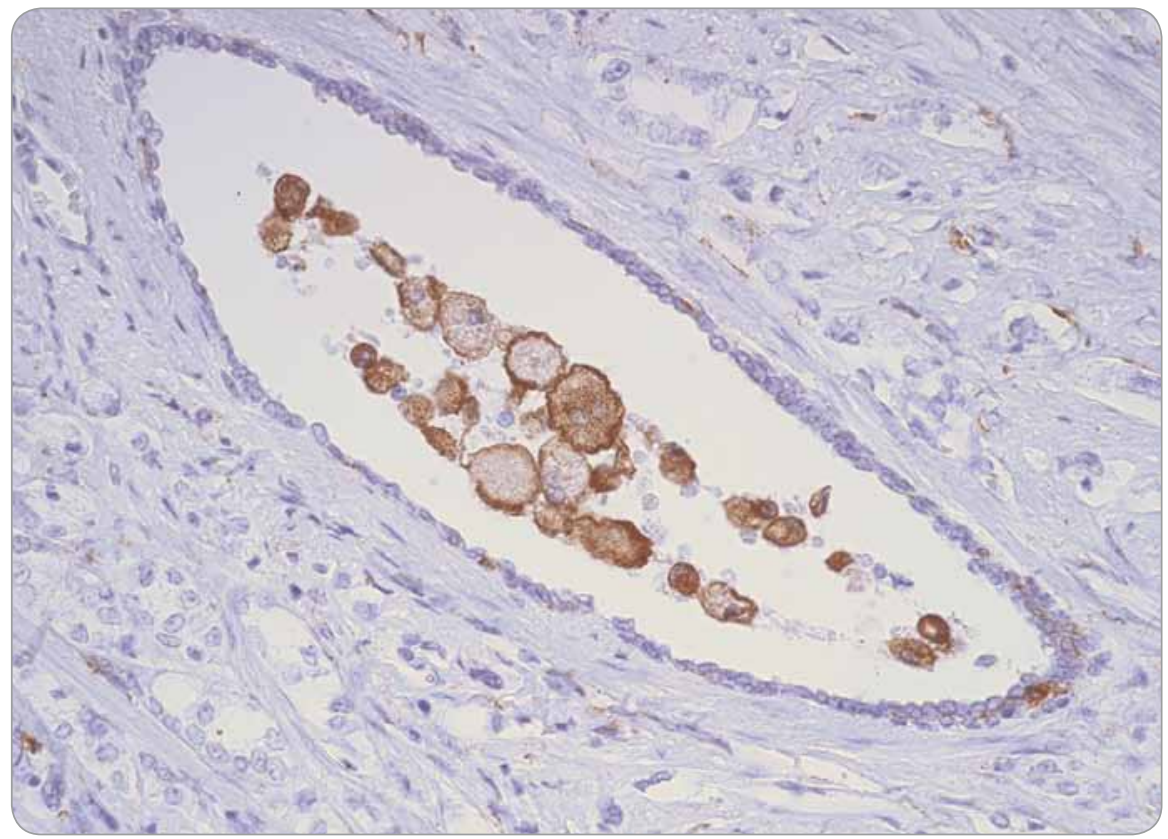

Fig. 1. CD204+ macrophages inside ductus crossing structures of prostate cancer.

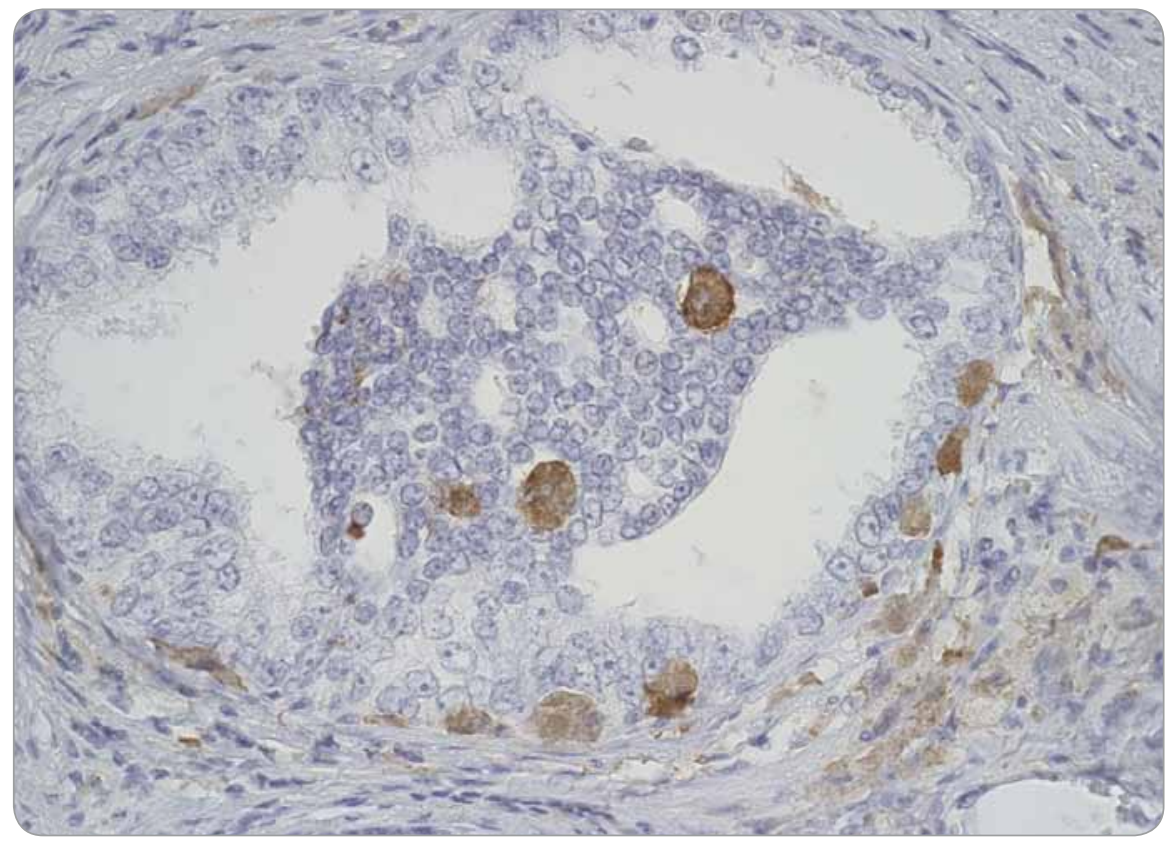

Fig. 2. CD204+ macrophages infiltrating structures of prostatic intraepithelial neoplasia.

ERG associated with the TMPRSS2-ERG fusion in a triple-color deletion assay. It also detects translocations involving the TMPRSS2 region. Formalin-fixed, paraffin-embedded tissue sections were used for interphase FISH. Deparaffinized tissue was treated with $0.2 \mathrm{M} \mathrm{HCl}$ (hydrochloric acid) for $20 \mathrm{~min}, \mathrm{NaSCN}$ (sodium sulphocyanide) for $30 \mathrm{~min}$ at $80{ }^{\circ} \mathrm{C}$ and digested with pepsin (SigmaAldrich, USA) for $70 \mathrm{~min}$. The tissues and FISH probe were co-denatured for $5 \mathrm{~min}$ at $80^{\circ} \mathrm{C}$ and hybridized overnight at $37^{\circ} \mathrm{C}$ in a humid chamber (StatSpin ThermoBrite, IRIS, Massachusetts, USA). FISH interpretation was carried out by a molecular cytogeneticist and a pathologist, both experienced in analysing interphase FISH experiments. Hematoxylin and eosin sections were available for side-by-side comparison with the FISH image to localise tumor 


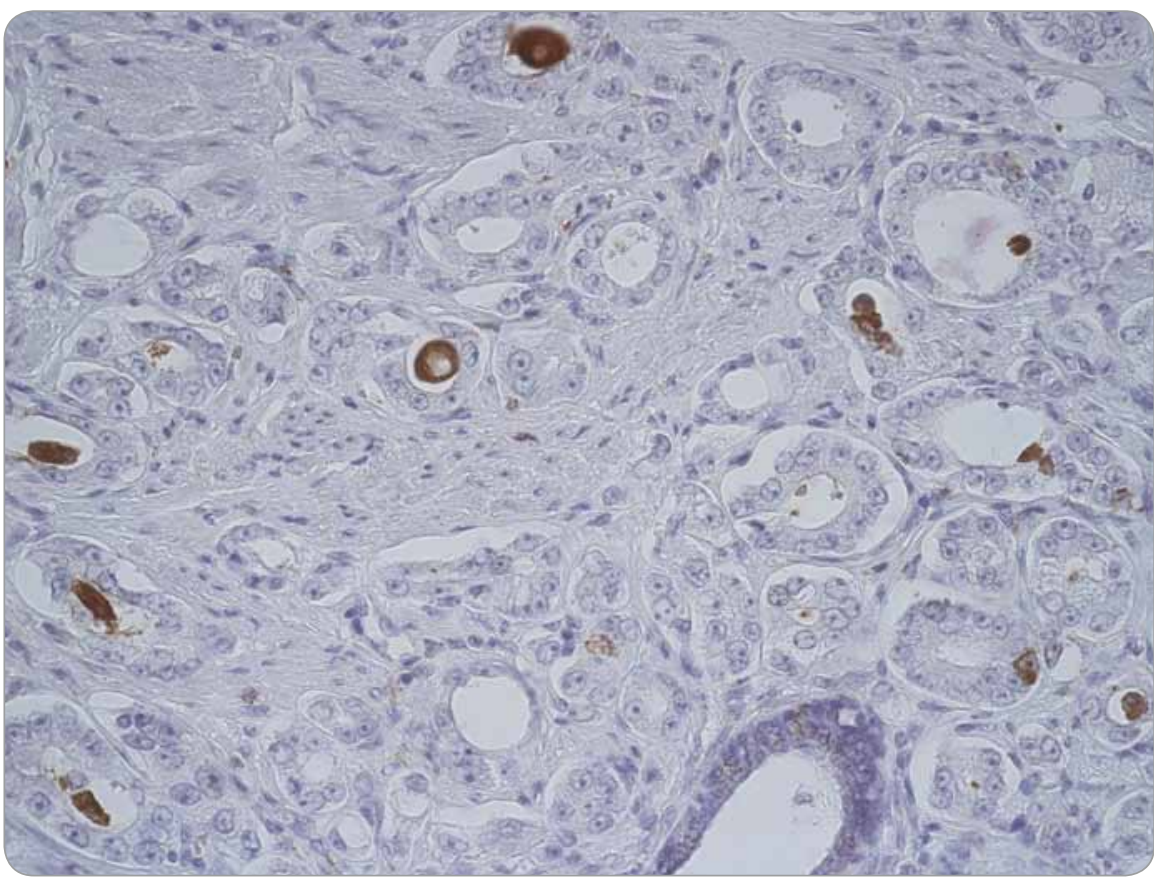

Fig. 3. CD204+ macrophages inside prostate cancer structures.

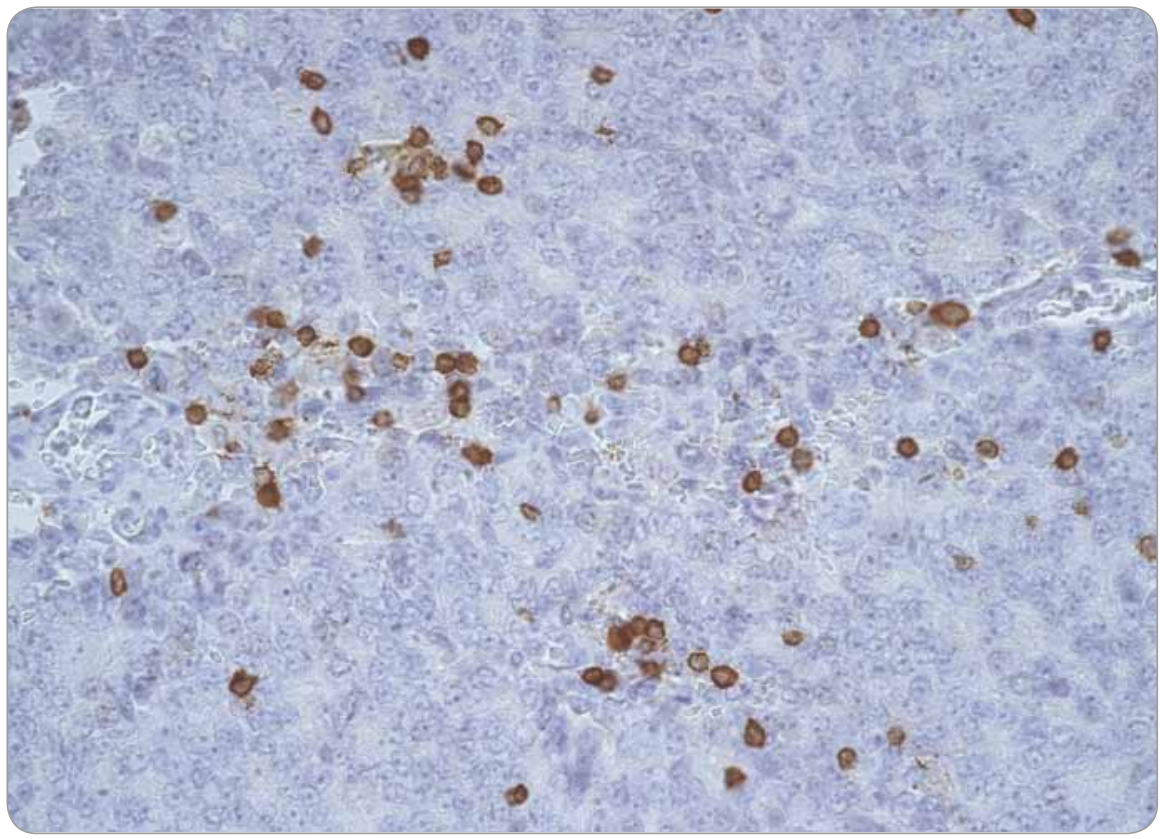

Fig. 4. CD3+ lymphocytes infiltrating prostate cancer structures.

cells. Paired benign prostatic epithelium was also evaluated as a negative control. Expected signal patterns according to instructions of the TMPRSS2-ERG probe manual - a nucleus with the TMPRSS2-ERG fusion (group 1 - TMPRSS2-ERG fusion) demonstrates loss of green signal leaving a red/blue signal at $21 \mathrm{q} 22$. A nucleus with a split of the probe in case a translocation at $21 \mathrm{q} 22$ (group 2 the fusion signal, observed as a single red and green/blue signal pattern at the derivative chromosomes, and a nucleus without TMPRSS2-ERG rearrangement (group 3 - normal signal pattern) demonstrated 2 pairs of juxtaposed green, red and blue signals. The samples were analysed under a $100 x$ oil immersion objective using an Olympus
BX-51 fluorescence microscope (Olympus, Center Valley, Pennsylvania) equipped with appropriate filters, a CCD (charge-coupled device) camera and captured by ISIS software (MetaSystems, Altlussheim, Germany).

Evaluation of the number of CD3+ and CD204+ cells was performed by the method of determining their average number in the field of view at the greatest magnification (high power magnification). Characteristic immunohistochemical staining patterns are shown in Fig. 1-4.

We divided the patients into subgroups according to the degree of infiltration of their CD204+ macrophages and CD3+ lymphocytes and according to difference of infiltration in benign, premalignant and malignant prostate structures. We interpreted this difference as the capability of immunocompetent cells to reflect the cancer development. Based on the capability of CD204+ and CD3+ cells to infiltrate the tumor structures, cells was divided as follows:

CD204+ infiltration: W - weak without significant changes in the number of positive cells (in comparison with $\mathrm{BPH}$ have $\mathrm{CaP}$ or PIN increase max. of 5 or decrease - weak reactivity), G - good (increase in CaP or PIN by more than 5 - good reactivity);

CD3+ infiltration: W - weak without substantial increase in positive cell count (in comparison with $\mathrm{BPH}$ have CaP or PIN increase by a max. of 5 weak reactivity), G - good (increase in $\mathrm{CaP}$ or PIN by more than 5 - good reactivity).

In addition, we performed an evaluation of the intensity of inflammation by the method evaluating the number of "hot spots" [13].

break in TMPRSS2) resulted in a break of

\section{Statistical analysis}

The data were analyzed using SPSS 15.0 software package (SPSS Inc., Chicago, Illinois, USA), and a two-tailed $P$ value of less than 0.05 was considered statistically significant. In the case that the Shapiro-Wilk test of normality revealed non-normal distribution, the nonparametric Kruskal-Wallis and Mann- 
-Whitney $U$ tests with Bonferroni correction were used. The relation of age to other tested parameters was performed by ANOVA.The multiple correlationswere assessed using the Spearman coefficient of determination, and categorial data were tested using the $X^{2}$ test and/or in the case of low numbers, the Fisher exact test.

\section{Results}

Infiltration of prostate lesions by CD204+ macrophages

The number of CD204 + macrophage infiltration is increasing in direction from $\mathrm{BPH}$ through PIN to CaP, regardless of fusion status (group 1 - TMPRSS2-ERG fusion; group 2 - break in TMPRSS2; group 3 - normal signal pattern). The number of CD204+ inflammatory cells was highest in group 1 and gradually declined downward in group 2 and the lowest number was observed in group 3 . A gradual decrease in the level of CD204+ cells infiltration in direction from group 1 to group 3 is evident primarily in $\mathrm{CaP}$ (14.1 - $10.0-5.5)$. Significant decrease is also visible in PIN lesions, however, there is no observed gradual decline (e.g. PIN 3.93 - 4.6 - 1.9). This decrease is not observed in BPH (Graph $1 \mathrm{~A}-\mathrm{C}$ ). The Kruskal-Wallis test showed that groups 1 and 3 significantly differed in the number of infiltrating CD204+ cells in PIN ( $p=0.005)$ and in CaP ( $p=0.0002)$. Groups 1 and 2 in CaP had a significantly higher CD204+ macrophages infiltration than group 3 with the $P$ values, $p \leq 0.001$ and $p \leq 0.015$, respectively (Graph 2).

\section{Infiltration of prostate lesions by CD3+ T-lymphocytes}

The increasing number of $\mathrm{CD} 3+$ T-lymphocytes in a direction from $\mathrm{BPH}$ through PIN to CaP, is only visible in group 3 (normal signal pattern) and less clearly for group 1 . The opposite trend was observed in group 2 (BPH 21.3; PIN 20.5; CaP 18.3). Also the absolute values of the number of $\mathrm{CD} 3+$ cells in the $\mathrm{CaP}$ structures, are not significantly different (Graph 1a, 1b, 1c). The Kruskal-Wallis test showed that groups 1 and 3 significantly differ in the number of infiltrated CD3+ cells in BPH $(p<0.0001)$.

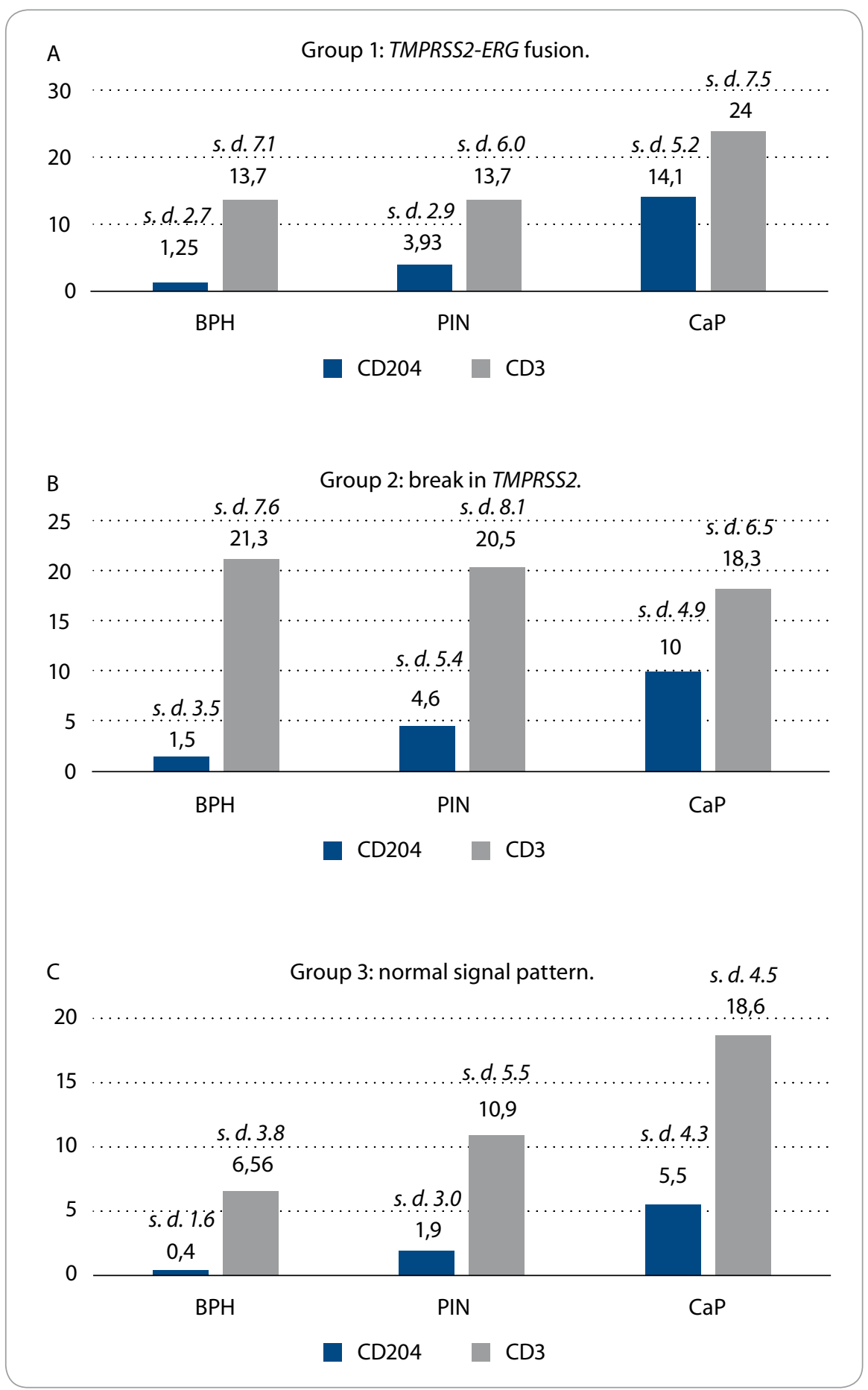

Graph $1 \mathrm{~A}-\mathrm{C}$. Kruskal-Wallis tests have shown that groups 1 and 3 differ in parameters CD204 PIN ( $p=0.005)$, CD204 CaP $(p=0.0002)$ and CD3 BPH $(p<0.0001)$.

$\mathrm{BPH}$ - benign prostatic hyperplasia, PIN - prostatic intraepithelial neoplasia, CaP - prostate cancer

Association between capability of CD204+ and CD3+ cells to reflect malignant transformation of prostate and gene rearrangement

We found that groups 1, 2 and 3 statistically significantly differed in the distribution of cases with CD204+ cells reactivity (Fisher exact test $p<0.0001$ ). Post hoc tests with Bonferroni correction show that groups 1 and 3 significantly differ $(p<0.0001)$. There were significantly more cases with good 


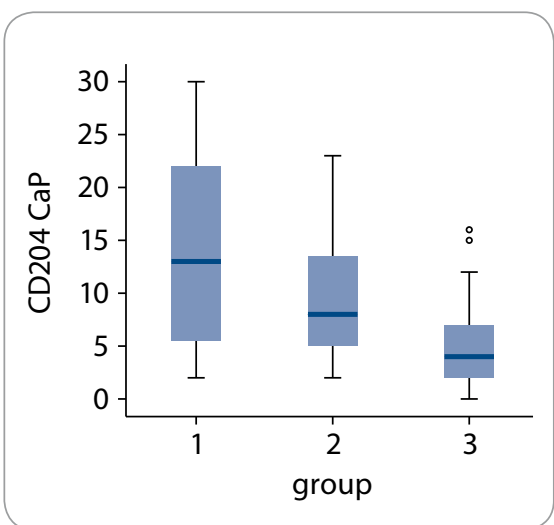

Graph 2. Group 1 had, in CaP, a significantly higher CD204+ macrophages infiltration than group $3(p \leq 0.001)$ and the group 2 had also significantly higher infiltration than group 3 ( $p \leq 0.015)$. $\mathrm{CaP}$ - prostate cancer

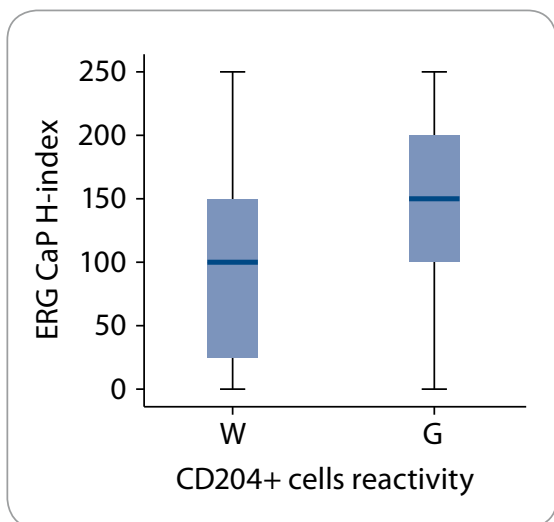

Graph 4. Using the Mann-Whitney U test, a higher ERG protein expression was shown in the cases with good reactivity of CD204+ cells (G) than in the cases with weak reactivity of CD204+ cells (W) $(p=0.047)$. $\mathrm{CaP}$ - prostate cancer, $\mathrm{H}$-index - histoscore

reactivity of CD204+ cells in group 1 (TMPRSS2-ERG fusion) compared to group 3 (normal signal pattern) where a weak reactivity of CD204+ cells predominated. Groups 1, 2 and 3 also differed statistically significantly in the distribution of CD3+ cells reactivity (Fisher exact test $\mathrm{p}<0.0001$ ). Post hoc tests with Bonferroni correction showed that groups 1 and $3(p=0.004)$ and groups 2 and $3(p<0.0001)$ were significantly different. There was no significant difference between groups 1 and $2(p=0.748)$. There were significantly more cases with good reactivity of $\mathrm{CD} 3+$ cells in group 1 and significantly

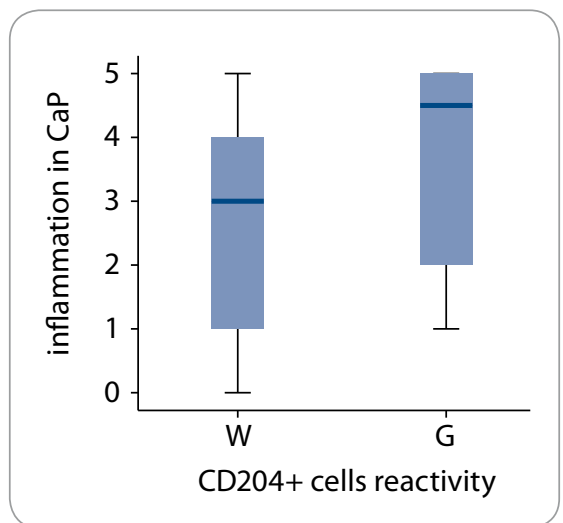

Graph 3. Cases with good reactivity of CD204+ cells (G) have in prostate cancer a significantly higher number of inflammatory hot spots than cases with weak reactivity of CD204+ cells (W) $(p=0.017)$. $\mathrm{CaP}$ - prostate cancer

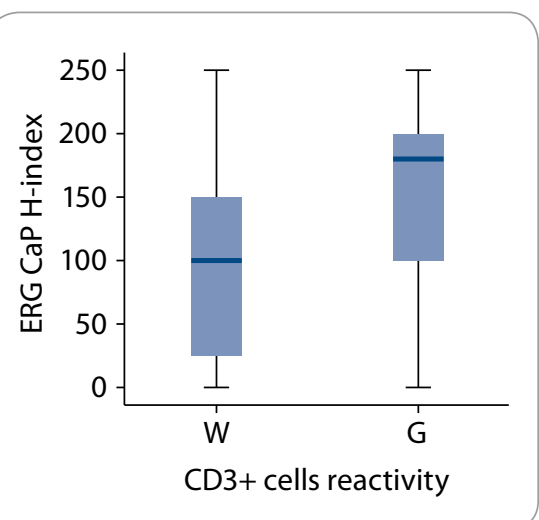

Graph 5. Using the Mann-Whitney U test, a higher ERG protein expression was shown in the cases with good reactivity of CD3+ cells (G) than in the cases with weak reactivity of $C D 3+$ cells $(W)(p=\mathbf{0} 0.003)$. $\mathrm{CaP}$ - prostate cancer, $\mathrm{H}$-index - histoscore

more cases with weak reactivity of CD3+ cells in group 3.

\section{Relationship between infiltration} of CD204+ and CD3+ cells, their capability to reflect malignant transformation, inflammation and ERG expression

Positive correlations between higher expression of ERG and higher infiltration of CD204+ macrophages $(p=0.0001)$ and CD3+ T-lymphocytes $(p=0.007)$ in the tumor microenvironment was observed only in cases with detected TMPRSS2ERG gene fusion (group 1). In cases with rearrangement in TMPRSS2 gene, a positive correlation was found only between ERG expression and CD204+ macrophage infiltration $(p=0.002)$. No correlation was found in group 3 (normal signal pattern). There was a significantly higher number of inflammatory hot spots in cases with good reactivity of CD204+ cells compared with cases with weak reactivity of CD204+ cells $(p=0.017)$ in the CaP (Graph 3).

Cases with good reactivity of CD204+ cells as well as CD3+ cells had significantly higher ERG expression in $\mathrm{CaP}$ than cases with weak reactivity of CD204+ cells or CD3+ cells $(p=0.047, p=0.003)$ (Graph 4, 5).

\section{Discussion}

Epidemiological studies of $\mathrm{CaP}$ show significant associations between inflammation and cancer. Cellular stress induced by inflammation causes repeated genomic damage leading to cellular transformation, vascularization and DNA mutation. Bacterial infection results in prostatic tissue infiltration with neutrophilic granulocytes, macrophages and lymphocytes. This results in the production of reactive oxygen, nitrogen radicals and various cytokines that change the tissue microenvironment, cause irreversible DNA damage and malignant transformation [10]. Inflammatory cells also produce and release a variety of enzymes, cytokines and chemokines that promote the growth and spread of tumor cells. On the other hand, inflammatory cells also participate in the immune response and some types of cells are associated with significant tumor suppression and antitumorigenesis. It is not yet clear, what type of the cells have carcinogenic or anti-tumor impact. Fujii et al. evaluated the significance of inflammatory infiltrates, which contain cells expressing CD3, CD4, CD8, CD20, CD79alpha, CD68 CD204 CD163 antigens and represent a broad spectrum of T-lymphocytes, B-lymphocytes and macrophages in prostate carcinogenesis [2]. They found that in general, the number of inflammatory cells in the infiltrate was highest in BPH and gradually decreased in PIN and CaP. Their findings were supported by Engelhardt et al [1]. Theyer 
et al. indicated that T-lymphocytes (70\%) prevail in prostate infiltrate, followed by B-lymphocytes (15\%) and macrophages (15\%) [14]. However, Fujii et al. found a significantly higher proportion of B-lymphocytes (59\%) in benign prostate structures, which significantly decreased in PIN and CaP (29-31\%) [2]. They found no significant differences in the presence of $\mathrm{CD} 3+, \mathrm{CD} 4+$ and $\mathrm{CD} 8+$ (T-lymphocytes) cells for BPH, PIN and $\mathrm{CaP}$. In this respect, our results concerning CD3+ T-lymphocytes are consistent with these findings, because differences, which we found between these structures, were not significant. A certain propensity to increased infiltration in malignant structures was observed only in the group with a normal signal pattern. The highest number of infiltrating CD3+ cells was detected in CaP and gradually declined in PIN and was the lowest in BPH. It is unclear whether these results were affected by the "bug of small numbers" or whether they indicate that the capability of CD3+ T-lymphocytes to infiltrate malignantly transformed lesions occurs through a mechanism independent of the presence of the fusion gene. CD3+ marker is expressed in all mature T-cells, which include different subtypes of lymphocytes with different functions. Therefore, it is not possible to determine what qualitative changes in the composition of T-cell lymphocyte subpopulations occur in the tumor or whether these changes have a supportive or inhibitory effect on the tumor.

Some papers highlighted the importance of macrophages producing chemotactic protein-1 (MCP-1) and emphasized that tumor infiltration by these TAMs correlates with a poor prognosis for some types of human malignancies. These macrophages express an antigen known as CD204. Wang et al. described an increase in the number of CD204+ macrophages in premalignant and especially malignant regions of analyzed tissue samples compared to BPH [15]. The authors concluded that CD204+ macrophages play a role in tumor development. However, it is not clear whether they are involved in promotion or inhibition of tumor progression. Macrophages can be classified according to their function as tumor-suppressive (M1 macrophages) and/or tumor-supportive (M2 macrophages). M2 macrophages are characterized by high production of IL-4 and IL-10 and low production of IL-12. They play important roles in tumorigenesis, angiogenesis, matrix remodelling, and metastasing. M2 macrophages express a "macrophage scavenger receptor $A$ " (MSR1, also known as CD204, SR-A - marker of alternatively activated macrophages) or a protein CD163, a member of the "scavenger receptor cysteine-rich domain" family $[2,7]$.

Fujii et al. also reported that CD204+ cells were more abundant in PIN and adenocarcinoma than in benign glands [2]. In contrast, infiltration of $\mathrm{CD68+}$ macrophages was high in $\mathrm{BPH}$ but reduced in PIN and adenocarcinoma. This disconcordance could be explained by the fact that not all $M 2$ macrophages have to be positive for the CD68+ marker. From these results, the authors suggested that the presence of CD204+ macrophages is an indicator of tumor progression. Recent studies have also reported the presence of $\mathrm{CD68+}$ or CD204+ macrophages in borderline and malignant tumors, including $\mathrm{CaP}$, glioma and pancreatic cancer $[16,17]$. Our results relating to CD204+ macrophages in $\mathrm{CaP}$ strongly support their tumor-supportive role. In the present study, we confirm an increased count of CD204+ macrophages in malignant structures. The number of infiltrating CD204+ macrophages increased from $\mathrm{BPH}$, via PIN to CaP, regardless of the TMPRSS2$-E R G$ gene fusion status. However, the grade of infiltrating CD204+ macrophages differed between groups with different fusion status (group 1 TMPRSS2-ERG fusion; group 2 - break in TMPRSS2; group 3 - normal signal pattern). In structures of CaP we found the most significant difference between TMPRSS2-ERG gene fusion status and grade of infiltration. The largest number of CD204+ infiltrating cells was detected in CaP with the TMPRSS2-ERG gene fusion, and the lowest number of these infiltrating cells was found in the $\mathrm{CaP}$ without this gene rearrangement (group
3 - normal signal pattern). It is known that ERG protein in CaP cells affects signalling mediated by prostaglandin positively and thus contributes to tumor progression. It appears that the existence of TMPRSS2-ERG fusion gene, or any other chromosome rearrangement in the TMPRSS2 gene, may stimulate the capability of CD204+ macrophages to infiltrate tumors. Our results confirm the important role of the ERG oncoprotein, which is overexpressed in the prostate due to the TMPRSS2-ERG fusion gene leads to modulation of inflammation in the prostate.

We report not only an association between the grade of CD204+ and CD3+ cells infiltration in tumor structures with the presence of the TMPRSS2-ERG gene fusion, but also with the expression of the ERG protein. The association between the TMPRSS2-ERG gene fusion and the different ability of inflammatory cells to infiltrate malignant structures has not been reported to date. This higher responsiveness of inflammatory cells for infiltrating malignant structures may not be a feature of an antitumorbased process that is associated with a better prognosis, but on the contrary, it may be an expression of inhibition of the immune system and induction of the immune tolerance. Nevertheless, a more accurate insight into the role of these infiltrating cells in prostate carcinogenesis and cancer progression is needed.

\section{References}

1. Engelhardt PF, Brustmann H, Seklehner S et al. Chronic asymptomatic inflammation of the prostate type IV and carcinoma of the prostate: is there a correlation? Scand J Urol 2013; 47(3): 230-235. doi: 10.3109/00365599.201 2.733961

2. Fujii T, Shimada K, Asai O et al. Immunohistochemical analysis of inflammatory cells in benign and precancerous lesions and carcinoma of the prostate. Pathobiology 2013; 80(3):119-126. doi: 10.1159/000342 396.

3. Stark T, Livas L, Kyprianou N. Inflammation in prostate cancer progression and therapeutic targeting. Trans Androl Urol 2015; 4(4): 455-463. doi: 10.3978/j.issn.22234683.2015.04.12.

4. Nakai $Y$, Nonomura N. Inflammation and prostate carcinogenesis. Int J Urol 2013; 20(2): 150-160. doi: 10.1111/j.1442-2042.2012.03101.x.

5. Ørsted DD, Bojesen SE. The link between benign prostatic hyperplasia and prostate cancer. Nat Rev Urol 2013; 10(1): 49-54. doi: 10.1038/nrurol.2012.192.

6. Hanada T, Nakagawa M, Emoto A et al. Prognostic value of tumor-associated macrophage count in 
human bladder cancer. Int J Urol 2000; 7(7): 263-269. doi: 10.1046/j.1442-2042.2000.00190.x.

7. Cao J, Liu J, Xu R et al. Prognostic role of tumour-associated macrophages and macrophage scavenger receptor 1 in prostate cancer: a systematic review and mate-analysis. Oncotarget 2017; 8(47): 83261-83269. doi: 10.18632/oncotarget.18743.

8. Martin SK, Kyprianou N. Gene fusions find an ERG-way to tumor inflammation. Cancer Biol Ther 2011; 11(4): 418-420. doi: 10.4161/cbt.11.4.14499.

9. Mohamed AA, Tan SH, Sun C et al. ERG oncogene modulates prostaglandin signaling in prostate cancer cells. Cancer Biol Therap 2011; 11(4): 410-417. doi: 10.4161/cbt.11.4.14 180.
10. Bartek J, Hamerlik P, Lukas J. On the origin of prostate fusion oncogenes. Nat Genet 2010; 42(8): 647-648. doi: 10.1038/ng0810-647.

11. Bostwick DG, Cheng L (eds.). Urologic surgical pathology. 2nd ed. Mosby Elsevier 2008.

12. Kolar Z, Burdova A, JamaspishviliT et al. Relation of ETS transcription factor family member ERG, androgen recep tor and topoisomerase $2 \beta$ expression to TMPRSS2-ERG fusion status in prostate cancer. Neoplasma 2014; 61(1): 9-16. doi: 10.4149/neo_2014_004.

13. Irani J, Levillain P, Goujon JM et al. Inflammation in benign prostatic hyperplasia: correlation with prostate specific antigen value. J Urol 1997; 157(4): 1301-1303. doi: 10.1016/S0022-5347(01)64957-7.
14. Theyer G, Kramer G, Assmann I et al. Phenotypic characterization of infiltrating leukocytes in benign prostatic hyperplasia. Lab Invest 1992; 66(1): 96-107.

15. Wang XY, Facciponte J, Chen X et al. Scavenger receptor A negatively regulates antitumor immunity. Cancer Res 2007; 67(10): 4996-5002. doi: 10.1158/0008-5472.CAN-06-3138.

16. Komohara Y, Ohnishi K, Kuratsu J et al. Possible involvement of the $\mathrm{M} 2$ anti-inflammatory macrophage phenotype in growth of human gliomas. J Pathol 2008; 216(1): 15-24. doi: 10.1002/path.2370.

17. Kurahara $\mathrm{H}$, Shinchi $\mathrm{H}$, Mataki $\mathrm{Y}$ et al. Significance of M2-polarized tumor-associated macrophage in pancreatic cancer. J Surg Res 2011; 167(2): e211-e219. doi: 10.1016/j.jss.2009.05.026. 